\title{
Reform and application of teaching methods in Higher Vocational English teaching
}

\author{
Zhao Hui Min ${ }^{1, a}$ \\ ${ }^{1}$ Bohai university, Jinzhou, 121013 China \\ ahmzhao2008@163.com
}

\begin{abstract}
Keywords: Higher vocational English; English teaching; teaching practice; teaching method; reform and Application.
\end{abstract}

\begin{abstract}
The development of high vocational and technical education puts forward many requirements to the reform of teaching objectives, teaching contents and teaching methods, the reform should be orientated to the application and practice in English teaching. With the rapid development and opening up of China's economy, it put forward more and more requirements for the English Teaching in higher vocational colleges. As a basic course, the teaching of higher vocational English should be orientated to the application, and the combination of study and practice, emphasizing the basic practicality and pertinence. The author analyzes the current situation of English Teaching in higher vocational colleges, and finds the existing problems, and puts forward the general idea of the reform of English teaching from the aspects of changing the idea, improving the teaching methods, reforming the testing methods.
\end{abstract}

\section{Introduction}

The unique requirements of teaching mode and talents training target of higher vocational education is established with the characteristics of Higher Vocational English teaching system in October 2000, the national Ministry of Education promulgated the "basic requirements of English Teaching of Higher Vocational Education" (hereinafter referred to as the "basic requirements"). "Basic requirements" pointed out that the education of Vocational English teaching is to enable students to master certain English knowledge and skills, have a certain listening speaking reading and writing and translation ability "," teaching requirements in strengthening English language basic knowledge and basic skills training at the same time, pay attention to the training of ability "the students to use English for communication, but also pointed out that there are two characteristics of Higher Vocational English Education: one is the practice of English learning process, two is the practical knowledge of English, it is also necessary and sufficient" with higher vocational education concept. This has decided that the higher vocational English teaching should take a new road which takes the training ability and the quality as the goal, which has put forward the new request and the standard for the foreign language teaching. How to better implement the "basic requirements" of the overall guiding ideology, adhere to the "practical oriented, adequate for the degree" principle is that we need to continue to explore new topics in the reform of English Teaching in Vocational colleges. English as vocational training courses must expressly scheme, meet the demands of modern society talent plays a very important role for training in higher vocational colleges, higher vocational colleges in current teaching [1], however there are still many problems need to be improved, how to better play the function and role of English Teaching in higher vocational colleges, educators study on the subject. This paper intends to present the problems of English Teaching in higher vocational colleges, and puts forward a general idea of the reform of English Teaching in Higher Vocational Colleges and discusses how to carry out reform.

\section{Analysis and existing problems of English Teaching in Higher Vocational Colleges}

\section{Students' English foundation is generally poor, weak foundation.}


Many students want to learn, but cannot start, from the psychological fear of English learning, psychological pressure, poor oral expression ability. According to the statistics of the questionnaire survey showed that $60 \%$ of the students are poor in English, word reading and writing difficulties; $30 \%$ of the students have a certain foundation, but not interested in learning English, cause the actual poor in English; 10\% of the students a good foundation in English, but affected by the whole environment for English learning, English reading, to improve the writing ability is relatively slow. In fact, the basis of English of students in higher vocational colleges is more serious than the statistics. The first question in the questionnaire: do you like learning English? From the survey results show that only $16 \%$ of the students choose to like, while $35 \%$ of the students are not very fond of, and even have $13 \%$ of the students chose not to like. Eighth questions in the questionnaire: will you take the initiative to find a chance to learn English? From the survey results show that $68 \%$ of the students choose the occasional, $22 \%$ of the students choose never [2].

\section{Students' English sensitivity is low.}

Tenth questions in the questionnaire: do you have a conscious attention to the English signs of public places and the English on the packaging of goods? From the survey results show that only 21\% of the students in the ordinary life of conscious attention to some of the English logo, and $45 \%$ of the students have chosen not to pay attention to these signs in English. Fifth questions in the questionnaire: how do you remember the words? The survey results show that $30 \%$ of the students choose the rote learning method, which shows that a large part of the students is not to find the most suitable for their English learning method, passive learning habits, "a bite, bite, lack of initiative. After entering higher vocational colleges, there is no pressure on the college entrance examination, they are playing to the extreme inertia.

\section{Most students learning objectives are not clear.}

With the development of network and multimedia technology, more and more are used as teaching aids in teaching. English as a language curriculum, English Teaching in higher vocational colleges should cultivate students' emphasis on listening and speaking ability of practical application, so in Higher Vocational College, but also need the network and multimedia teaching tools. Network and multimedia teaching is characterized by strong visibility, and can be interactive. For higher vocational colleges audio-visual course, suggestions open some more English cartoon audio-visual to stimulate students' interest in learning English, because English cartoons often use word simple, clear pronunciation and simple and interesting to attract the students. Performance in their future confusion, no long-term goals and short-term goals, but also for their own understanding is not clear, cannot correct self positioning, to learn English lost confidence.

\section{General thoughts on the reform of English Teaching in Higher Vocational Colleges}

\section{Effective use of multimedia teaching methods, to carry out interest in Teaching.}

With the development of network and multimedia technology, more and more are used as teaching aids in teaching. English as a language curriculum, English Teaching in higher vocational colleges should cultivate students' emphasis on listening and speaking ability of practical application, so in Higher Vocational College, but also need the network and multimedia teaching tools. Network and multimedia teaching is characterized by strong visibility, and can be interactive. For higher vocational colleges audio-visual course, suggestions open some more English cartoon audio-visual to stimulate students' interest in learning English, because English cartoons often use word simple, clear pronunciation and simple and interesting easy to attract students. Higher vocational college students as English foundation is different from that of the vast majority of students' English level are not high. Therefore, the school vocational college students, to deal with the level of testing, especially the test of oral and listening ability. After the test, according to test results with classes, teaching according to the students' English level. According to the difference of the quality of students, students can be divided into several groups, making different teaching goals, adopt different teaching methods, the 
implementation of group teaching, to all levels of students can learn, study, eventually adapt to the different needs of the community, to achieve training objectives.

\section{Establish an appropriate evaluation system of Higher Vocational English Teaching.}

The establishment of Higher Vocational English teaching evaluation system must first determine the evaluation standard, this standard should be determined in Higher Vocational English teaching goal oriented, now many schools do not have the appropriate English teaching evaluation system, only the application ability of English national higher school AB grade exam pass rate as the index of success in Higher Vocational English teaching, this there is a certain one sidedness. The author believes that the evaluation system of Higher Vocational English teaching is not only to consider the qualified rate of some of the English exam, but also consider the evaluation model can reflect the real level of English students, and evaluate whether the way in line with the needs of the students in the future work. Most of the higher vocational teachers have not really realized the particularity of Higher Vocational Education from the thought, and the traditional way of teaching is more and more. From the higher vocational English teaching, in the teaching process, teachers tend to grammar teaching, cultivating reading ability, sentence words, but ignore the cultivation of students' practical ability, so easily lead to "disjunction culture" and "demand". This approach obviously does not adapt to the requirements of higher vocational education, but also does not meet the social needs. The majority of teachers in English teaching should adapt to the economic and social needs of the new situation and new tasks, first of all to the change of education concept as a guide, to further improve the teachers' understanding of higher occupation education is employment oriented, establish vocational talents concept, quality concept, and the concept of teaching. Adhere to the purpose of improving the quality of personnel training, in order to cultivate technical talents as the theme, to further clarify the guiding ideology of the reform of English teaching. Correctly grasp the basic theory of English for the purpose of application, required for sufficient degrees in Higher Vocational English teaching, teachers should break the traditional imparting knowledge, exam for the purpose of teaching mode, to establish occupation demand oriented [3], with the ability as the center of the new teaching system, training of students basic knowledge of English the professor and the practical ability of English application. Adhere to the "necessary and sufficiency" principle, make the students learn a little, a little, a little, learn to use, so that the reform of English teaching has the characteristics of Higher Vocational education.

\section{Improvement of teaching method.}

The role of traditional classroom teaching and emphasize the outstanding teachers, teacher centered (teacher- centered), the teacher said in class, the students take notes in class, the whole class teacher to a person not to mind taking the trouble to explain vocabulary, collocation, sentence structure, grammar knowledge and translation of various texts, students desperately notes, at all no time to think. This "cramming" teaching students to use English makes no chance, cannot express your ideas in English, seriously hindered the development and use of students' language ability, to further improve the students' English level. Compared with ordinary college students, English, vocabulary, weak foundation of the Higher Vocational College Listening and speaking ability is poor, these characteristics determine that the traditional teaching methods for higher vocational students is even more confused. Therefore, it is imperative to reform the English teaching methods of higher vocational students to improve their English proficiency. The important characteristic of higher vocational education is the training of vocational skills, so that students have a good quality of skills in their respective jobs. Therefore, the teaching of English in higher vocational colleges must change the role of the classroom, and change the role of the classroom to achieve "training students to master the necessary and practical English language skills". In Higher Vocational English teaching process should be changed from the previous "What I say goes." teaching methods, namely to Teacher Center (teacher-centered) is the student center (student-centered). The so-called student-centered teaching method is also in the classroom activities, students for students to read the text by the protagonist, explained by everyone, my classmates can change, but the teacher is the organizer, instructor 
(organizer) (adviser), participants (participant), helper (helper), coordinator (mediator) and judge (assessor). Because the language is not a "church", is "practice", so we must emphasize the students' active participation enthusiasm, teachers should try to arouse students, encourage students to participate in teaching, exert their subjectivity, but also to give the right guidance and help. In the classroom, teachers make a necessary explanation, can ask the students to read the dialogue free combination, and according to the typical pattern of dialogue, let students write the content of small dialogue similar simulation stage performances, then chosen by the students in this class of excellent partner, to praise and encouragement, this approach can make they encouraged, there will be a sense of accomplishment, so that they will soon overcome the fear, shyness and other mental disorders, bold expression in English[4].

\section{To cultivate students' self-learning ability.}

Self learning is an important way to acquire knowledge in life, so that students master the science of self-learning, will benefit them for life. For higher vocational students, it should be very pay attention to the daily teaching in the cultivation of their ability. First teach students how to correctly use the tool book, how to quickly find the specific meaning of words. Before class, arrange the students to preview the task and ask them to take the problem to class. Arrange a certain amount of reading exercises after class, and regularly check their reading after class. In this way, we can improve the students' self study ability. The cultivation of students' language skills, only in the first classroom teaching in the implementation of "basic requirements" is not enough, it must be based on "basic requirements" to "organize students to participate in the rich and colorful English extracurricular activities, create a good atmosphere for learning English". Therefore, we are in the reform of classroom teaching, at the same time, efforts to create an extracurricular English communication environment for students. We will create an English corner, regularly organize English film appreciation, English Vocabulary Contest, English writing contest, English speech contest, English singing contest etc. These "second classroom" activities in English give students to learn in the first class in the language knowledge to real life opportunities, encourage them to work harder in order to improve the English level.

\section{Future development direction}

\section{Optimize the construction of teaching materials.}

The reform of teaching content is the primary task of Higher Vocational College English teaching reform, and the reform of teaching material is an important part of the reform of teaching content. English textbooks of vocational college should emphasize the practicability and interest, always carry out listening ability, purpose, follow the rules of the language learning, to learn the first language as a skill training, but is not only the process of imparting knowledge. The text should not be too long, but there are practical and easy to cause the discussion, students not only to understand the content of the text, but also can use English text about the content to express their opinions; listening and speaking should cooperate with each other to create the scene, and from easy to difficult, step by step, to enable students to constantly strengthen language sense in the process to hear, accurate and fluent. Most grammar training must be combined with oral training. Overall outstanding reading and translation ability of the training, taking into account the listening, speaking and writing of the basic training. This textbook can be heard, really let students have more practice opportunities, conducive to the creation of micro language environment, completely got rid of "dumb English" bad habits. Teaching materials show practical, practical and practical.Effect of "phantom" characteristics, so that the English proficiency of students and the actual foreign communication and social needs more closely integrated.

\section{Using modern teaching methods.}

Higher Vocational College English teaching should abandon the mode of learning English by teaching materials, and improve students' ability to use English effectively by using various kinds of 
media and adopting various channels to receive input. The modernization of teaching means plays an important role in improving the quality of teaching. Nowadays, it has become a symbol of the reform of English teaching means to promote the modernization of multimedia based teaching. Increase in foreign language teaching courses and courses and improve the utilization of existing equipment, the establishment of foreign language audiovisual information system, improve teaching methods, but more important is people, namely the teacher. The modern teaching means cannot do without mastering modern educational technology teachers; therefore, teachers should study modern educational technology, the full development of advanced teaching equipment, as soon as possible to change the concept of education, to update the concept of education, to adapt to the requirements of modern teaching.

\section{Pay attention to the main role of students in Teaching.}

Higher vocational English Teaching in the past, often for a single teacher imparting knowledge, students passively accept the situation, pay attention to the "preaching", both "industry", ignore "faq". Now the implementation of the appropriate "preaching", focusing on "teaching", advocate "doubts", namely the selection of appropriate theoretical knowledge and necessary teaching; according to the needs of the professional characteristics and employment, guiding students to optimize learning method, master the ability to use English; to guide students in the training practice to discover and analyze problems and solve the problem. Change the passive acceptance of students as the active learning, change simply accepts the theoretical knowledge for the use of theoretical knowledge and learning methods to improve the ability of English application. In this way, it reflects the subjective initiative of students in teaching, the creativity of solving problems, the dynamic of teaching process and the optimization of teaching effect [5].

\section{Summary}

The reform of English Teaching in higher vocational colleges is a systematic project, the need for concerted efforts to make perfect, in English learning enthusiasm and initiative to make better use of existing teaching resources to mobilize students, not only to the English class the students returned to the classroom, let the students get the fun of learning English in English class, really to improve students' English level and meet the needs of the job in the future. As an English teacher in higher vocational colleges, we should explore and reform bravely and try to push the higher vocational English teaching to a new level, and cultivate more qualified higher vocational and technical personnel.

\section{Acknowledgements}

This work is supported by Social Science Foundation of Liaoning Province (No. L15DWW005) and Bohai University Teaching Reform Project (No.BDJG15QNB002).

\section{References}

[1] Fan Xiaoxia. Experimental study on the integration of Public English and accounting English Teaching in Higher Vocational Colleges [J]. Journal of Jilin radio and TV University (08) (2016).

[2] Wang Yongmei. Discussion on the application of micro teaching resources in the teaching of Public English course in Higher Vocational Colleges [J]. overseas English 2016 (09).

[3] Cai Haixia. Research on the connection between public English and professional English Teaching in Higher Vocational Colleges -- Taking Wuxi Urban Vocational College as an example [J]. Journal of Changchun Institute of education. 2014 (18). 
[4] Feng Xiaoni. Enterprise needs and the convergence of Higher Vocational Public English curriculum problems and Countermeasures [J]. modern economic information. 2015 (13).

[5] Qiang Allison. Public English classroom of Vocational College Students' negative behavior to explore new campus [J]. (early) 2015 (11). 